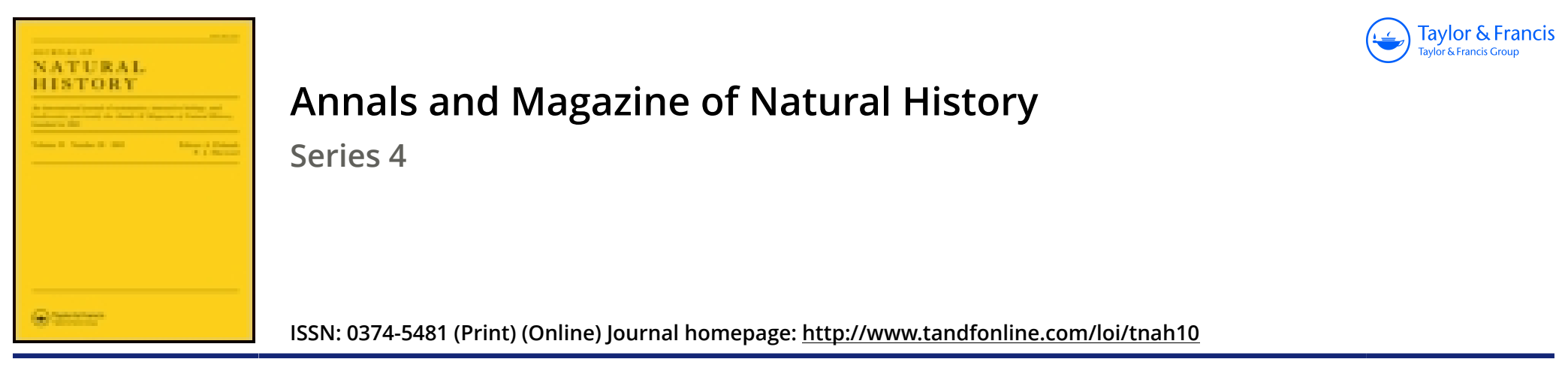

\title{
VII.-On the branched form of the Apertural prolongation from the summit of Carpenteria monticularis
}

\section{H.J. Carter F.R.S.}

To cite this article: H.J. Carter F.R.S. (1877) VII.-On the branched form of the Apertural prolongation from the summit of Carpenteria monticularis, Annals and Magazine of Natural History, 20:115, 68-70, DOI: 10.1080/00222937708682193

To link to this article: http://dx.doi.org/10.1080/00222937708682193

曲 Published online: 13 Oct 2009.

Submit your article to this journal $\pi$

Џll Article views: 1

Q View related articles $\sqsubset$ 
VII.--On the Branched Form of the Apertural Prolongation from the Summit of Carpenteria monticularis. By $\mathrm{H}$. J. Carter, F.R.S. \&c.

In my paper on Foraminifera ("Annals,' 1877, vol. xix. pl. xiii. fig. 11) I have represented what appeared to me to be an embryonic form of Carpenteria monticularis, besides two forms of the matured test (fig. $9, a, b$ ); and by referring to the former it will be observed that there is a tubular prolongation of the aperture from the summit, whose margin (or, at least, that portion of it which remains entire) shows that it was inflated i.e. thickened and rounded, as in the aperture of Polytrema miniaceum ('Annals', 1876, vol. xvii. pl. xiii. fig. $6, c, \& c$.$) .$

In the figure of the matured form $(a)$ the margin was also inflated and smooth, while that of " $b$ " presented a jagged edge, from which a portion had evidently been broken off.

Just now, on a small branch of Oculina rosea (loc. unknown), I have met with a matured specimen of Carpenteria monticularis like that of " $a$ " (l.c.), in which the aperture is prolonged into a tubular form that at first divides into two branches, one of which has been broken off just after the division; but the other, which remains, may be assumed to indicate what the former might have been. After a certain distance the remaining branch sends off three divisions, two of which have been broken off, while the third extends upwards for some distance, where the jagged form of its extremity also indicates that this is not its original termination, which probably had an inflated smooth margin. Thus in this spccimen of Carpenteria monticularis the tubular pro-

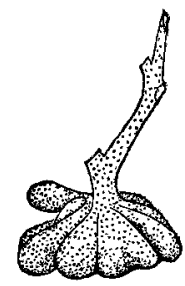

Carpenteria monticularis, $\times 8$.

longation of the aperture at the commencement divided into two branches, which were afterwards subdivided (see woodcut, magnified about eight diameters).

By its side was another matured form like " $b$ " $(l . c$.$) , in$ 
which the tubular prolongation was also divided into two branches, both of which had been broken off; while close by are several embryonal forms of Polytrema miniaceum, which also end respectively in an erect tubular prolongation of the aperture, terminated by an inflated and everted margin like that of fig. $6, c(l . c$.$) , whose form, at first single, be-$ comes multiplied as the Polytrema increases in size.

The erect, branched, tubular extension of the aperture in C. monticularis therefore shows what Max Schultze had anticipated when he modestly said:- "Perhaps my observations on Polytrema, which indicate the remarkable affinity between that genus and Carpenteria, may serve to shake Carpenter's faith in his opinion" ('Annals,' 1863, vol. xii. p. 419).

The entire tubular extension of the aperture in $C$. monticularis to which I have alluded is a little more than 1-12th inch long, 1-45th inch in diameter at the fixed end, and $1-138$ th inch in diameter at the free extremity of the ultimate branch, which, as before stated, has been broken off.

It first commences in an undivided portion, about 1-36th inch long, which then bifurcates, when one of the branches is broken off, but measures, like the other at this point, 1-72nd inch in diameter. The branch which has not been broken off is then continued on for 1-50th inch, when it sent off a branch which is now indicated by a projecting aperture with inflated margin, that may or may not have ever been longer than it now is; just after which the continuation of the tube divides into two other branches of unequal size, one of which, viz. the largest, has also been broken off just after the bifurcation, where it is 1-72nd inch in diameter, while the other is continued on for about 1-33rd inch, when it also ends in a broken extremity where the wall of the tube is about 1-1800th inch thick and the tube itself 1-138th inch in diameter, which, from this diminished size, I should think, must have been very near its original termination.

The tubular branched prolongation is cylinorical and circular throughout, and increases gradually in the thickness of the wall as well as in the diameter of the tube from the free ends to the fixed one. Moreover it is more or less filled with linear spicules, some of which appear to be incorporated longitudinally with the inner part of the wall of the tube; while throughout also it is sparsely punctate with the tubulation common to the foraminiferal test. So that altogether C. monticularis thus bears a considerable resemblance to Polytrema; and commencing in the embryonic form (fig. and $l$.c.) with a 
single tubular prolongation (which, as the Carpenteria increases in size, becomes branched and thus multiplied), it also becomes even more subdivided than the branching in Polytrema.

What, therefore, takes place in the tubular prolongation of the aperture in $C$. monticularis may also be the case in $C$. balaniformis and in $C$. (Polytrema) utricularis; but being so delicate that the slightest force almost breaks it off, there is very little chance of a specimen of either coming into our possession with the tubular prolongation even in the imperfect state of that above mentioned; hence the rarity. While in the living state, where broken off, the margin becomes smoothed down, rounded, and thus inflated by the animal, which form presents a marked contrast with the jagged appearance occasioned by fracture after death. Thus a natural and a fractured margin may be readily distinguished. When the tubular prolongation of either Polytrema or Carpenteria is preserved, it will probably be found to arise from the specimens being situated in depressions which have protected them from coming into contact with such force as must have broken it off; for the tubular prolongation of the embryonic Polytrema cannot be touched with the point of the finest hair-pencil without risk of breaking; and therefore, when found in a dusty state (which is generally the case), no attempt to clean it in this or any way should be made, or the probability is that the delicate extremity, with the few spongespicules that generally project from it, will be destroyed.

\section{VIII.-On the Salenidx, Wright.-Part I. Observations on the Morphology of a Recent Salenia. By P. MarTin Duncan, F.R.S., Pres. Geol. Soc.}

[Plate II. B.]

HAving been lately engaged in studying the comparative morphology of the group of Salenidx, some interesting and rather important points in the structure of a recent specimen probably referable to Salenia varispina, A. Agassiz, have come to light.

The Salenidæ, according to Wright, form a natural family of the Echinoidea Endocyclica, their characteristics being "the peculiar structure and great development of the apical disc, which, besides the five genital and five ocular plates, has an additional or suranal plate developed in the centre of the 